\title{
Exploration of Some Medicinal Plants Used in Saudi Arabia and Their Traditional Uses
}

\author{
Bassam SM Al Kazman* \\ Department of Pharmacognosy, School of Pharmacy, Najran University, Saudi Arabia \\ *Corresponding author: Bassam SM Al Kazman, Department of Pharmacognosy, School of Pharmacy, Najran University, \\ P.B. Box 1988, Najran 11001, Saudi Arabia
}

ORCID: 0000-0002-6070-3512

\section{ARTICLE INFO}

Received: 慧 October 25, 2021

Published: 幽 November 08, 2021

Citation: Bassam SM Al Kazman. Exploration of Some Medicinal Plants Used in Saudi Arabia and Their Traditional Uses. Biomed J Sci \& Tech Res 39(5)-2021. BJSTR. MS.ID.006359

\begin{abstract}
Since ancient times, medicinal plants (MPs) have been used globally for the treatment of various diseases especially in traditional medicine. In the Arab world, MPs are crucial healthcare sources due to they are salient elements of prophetic medicine and long history of MPs research in the Arabian Peninsula. In Saudi Arabia, people have been using MPs to heal several human and livestock diseases. The current review discussed 20 species that are reported in Saudi Arabia for traditional uses. This study also reported the medicinal significance of some of these species in the treatment of various diseases. However, more studies should be accomplished for the pharmacological, phytochemical screening and toxicological in order to assure their toxicity profile and biological activity. This study aims to discuss the traditional uses of some medicinal plants that grow in different regions of the kingdom.
\end{abstract}

Keywords: Medicinal Plants; Traditional Uses; Saudi Arabia; Biological Activity

\section{Introduction}

Since ancient times, medicinal plants (MPs) have been used globally for the treatment of various diseases especially in traditional medicine [1]. MPs are a part of folk medicine and various parts of the plant are used such as flowers, leaves, barks, roots and seeds $[2,3]$. It has been suggested that MPs are the greatest source to obtain different drugs and approximately $80 \%$ of developed countries' populations use traditional medicine [4]. In the Arab world, MPs are crucial healthcare sources due to they are salient elements of prophetic medicine and long history of MPs research in the Arabian Peninsula [2]. In Saudi Arabia, people have been using MPs to heal several human and livestock diseases [5]. Additionally, folk medicine is a remarkable aspect of people's cultural heritage of Saudi Arabia and was utilized even before the introduction of biomedicine [2]. Geographically, Saudi Arabia is characterized by a variety of habitats for instance, valleys, meadows, mountains, lava fields and rocky deserts [5]. The southwestern region of Saudi Arabia is the richest in both species diversity and the number of endemic species compared to other regions [5]. The flora of Saudi Arabia contains many MPs with more than 2250 species and a high proportion $(24.57 \%)$ of these species have been used for medicinal purposes (Figure 1) [6]. These plants have been documented in two volumes named "Medicinal Plants of Saudi Arabia" and published in 1987 and 2000 [2]. The usage of these plants in the treatment of various diseases such as asthma, cancer, hepatic and neurological diseases was reported as $80 \%, 55 \%, 90 \%$ and $42.3 \%$ respectively [7]. Most of the MPs of Saudi Arabia are belonging to various families involving Labiatae, Compositae, Polygonaceae, Euphobiaceae, Leguminosae, Amaranthaceae, Capparidaceae and Solanaceae (Table 1) [8]. This study aims to discuss the traditional uses of some medicinal plants that grow in different regions of the kingdom. 


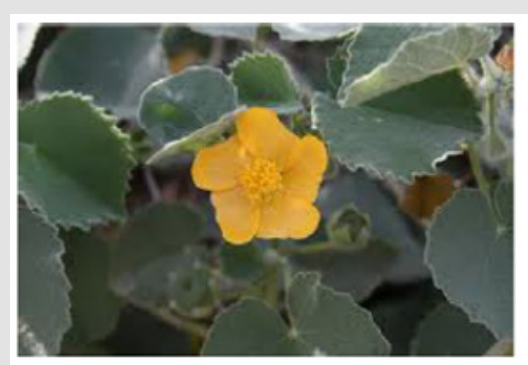

Abutilon figarianum Webb

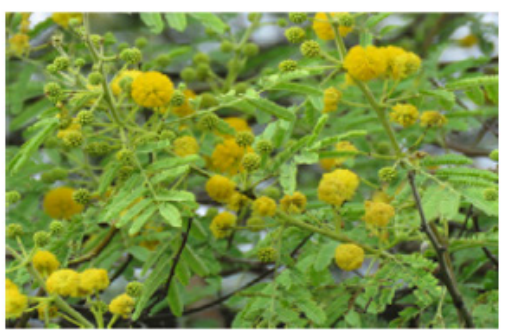

Acacia arabica

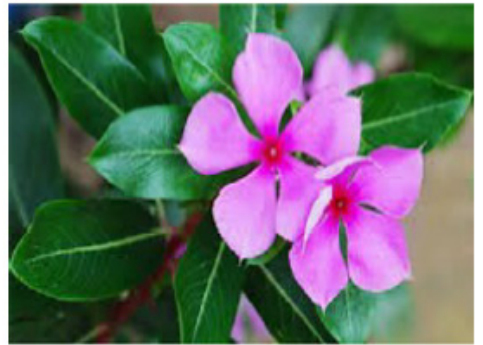

Catharanthus roseu

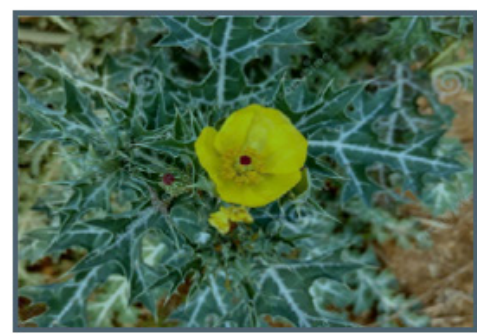

Argemone Mexicana

Figure 1: Photograph of some medicinal plants [7].

Table 1: Number of traditionally reported species per family in Saudi Arabia [9].

\begin{tabular}{|c|c|c|c|c|c|}
\hline Family Name & Number of Species & Family Name & Number of Species & Family Name & Number of Species \\
\hline Labiatae (Lamiaceae) & 33 & Adiantaceae & 1 & $\begin{array}{c}\text { Brassicaceae } \\
\text { (Cruciferaceae) }\end{array}$ & 17 \\
\hline Polygonaceae & 8 & Aizoaceae & 4 & Cactaceae & 1 \\
\hline Euphorbiaceae & 26 & Annonaceae & 1 & Cannabaceae & 1 \\
\hline Amaranthaceae & 13 & Apocynaceae & 10 & Caryophyllaceae & 2 \\
\hline $\begin{array}{c}\text { Capparaceae } \\
\text { (Capparidaceae) }\end{array}$ & 8 & Aristolochiaceae & 1 & Chenopodiaceae & 15 \\
\hline Solanaceae & 20 & Asphodelaceae & 4 & Cleomaceae & 6 \\
\hline Acanthaceae & 5 & Boraginaceae & 13 & Commelinaceae & 1 \\
\hline Convolvoulaceae & 9 & Moraceae & 4 & Rubiaceae & 1 \\
\hline Cupressaceae & 2 & Myrtaceae & 5 & Salvadoraceae & 1 \\
\hline Cynomoriaceae & 1 & Plantaginaceae & 4 & Tamaricaceae & 3 \\
\hline $\begin{array}{c}\text { Fabaceae } \\
\text { (Leguminosae) }\end{array}$ & 49 & Zingiberaceae & 4 & Verbenaceae & 2 \\
\hline Fumariaceae & 1 & Zygophyllaceae & 7 & Papavaraceae & 3 \\
\hline Graminae (Poaceae) & 13 & Liliaceae & 4 & Nyctaginaceae & 2 \\
\hline Malvaceae & 5 & Portulacaceae & 2 & Menispermaceae & 2 \\
\hline
\end{tabular}

Traditional and Ethnomedicinal Uses of Medicinal Plants of Saudi Arabia

Traditionally, various MPs have been used widely in Saudi Arabia for instance, Juniperus procera belongs to Cupressaceae family used for treating gastrointestinal disturbances, hepatic diseases, anti-rheumatism, jaundice and various inflammatory conditions [9]. Moreover, Rumex nervous is one of the major genera of Polygonaceae family reported by native people as anti-rheumatic, anti-pyretic, diuretic, anti-hypertensive, anti-scabies, aphrodisiac, anti-rabies, anti-hemorrhoids, anti-emetic, anti-tussive, and to heal leprosy, gonorrhea and lung tuberculosis [10]. Additionally, Ziziphus spina-christi is locally known as "Sidr" that belongs to the 
Rhamnaceae family and the leaves of it this plant used to treat skin diseases, sore, wounds and as antipyretic and antiulcer [11]. In the Bedouin, the fresh fruits and decoction of the stem bark of Ziziphus spina-christi are used to treat tuberculosis, bronchitis and to cure fresh wounds [12]. For more information about the traditional uses of MPs grow in Saudi Arabia see (Table 2) [13-20].

Table 2: List of some MPs recorded in Saudi Arabia and their traditional uses.

\begin{tabular}{|c|c|c|c|c|c|}
\hline Scientific Name & Family & Parts used & Medicinal uses & Utilization Method & References \\
\hline $\begin{array}{l}\text { Abutilon figarianum } \\
\text { Webb }\end{array}$ & Malvaceae & Whole plant & $\begin{array}{l}\text { Relieving muscle pain and } \\
\text { healing wounds. }\end{array}$ & Not reported & {$[13]$} \\
\hline Blepharis ciliaris (L.) & Acanthaceae & $\begin{array}{l}\text { Leaves, seeds and } \\
\text { roots }\end{array}$ & $\begin{array}{l}\text { Fever, astringents, appetizer, } \\
\text { cough, asthma, wounds, sores } \\
\text { and pruritic. }\end{array}$ & $\begin{array}{l}\text { Decoction of leaves, } \\
\text { roots and seeds is } \\
\text { taken orally }\end{array}$ & {$[5]$} \\
\hline Allium cepa L. & Amaryllidaceae & Bulb & $\begin{array}{l}\text { Respiratory, skin and throat } \\
\text { infections. }\end{array}$ & $\begin{array}{l}\text { Infusion, decoction, } \\
\text { juice in food. }\end{array}$ & {$[2]$} \\
\hline $\begin{array}{l}\text { Cinnamomum } \\
\text { zeylanicum }\end{array}$ & Lauraceae & Bark & $\begin{array}{l}\text { Uterine and ovarian diseases, } \\
\text { cough, catarrh, diuretic, laxative } \\
\text { and blurred vision pimples. }\end{array}$ & Not reported & {$[14]$} \\
\hline Acacia arabica & Fabaceae & Whole plant & $\begin{array}{l}\text { Haemorrhae, diarrhoea, scurvy, } \\
\text { dysentery scurvy, and colds }\end{array}$ & Not reported & [7] \\
\hline B. edulis (Forssk.) Pers. & Acanthaceae & Flowers & Upper respiratory tract infection. & Infusion & {$[15]$} \\
\hline $\begin{array}{l}\text { A. javanica (Burm. f.) } \\
\text { Juss. ex J.A. Schultes }\end{array}$ & Amaranthacea & Leaves and roots & $\begin{array}{l}\text { Healing wounds and as } \\
\text { hemostatic. }\end{array}$ & $\begin{array}{l}\text { Powder applied } \\
\text { topically }\end{array}$ & {$[15]$} \\
\hline $\begin{array}{l}\text { Ajuga bracteosa Wall. } \\
\text { ex Benth }\end{array}$ & Lamiaceae & Leaves and fruits & $\begin{array}{l}\text { As antiseptic and for teeth pains, } \\
\text { diuretic and in treatment of } \\
\text { Rheumatism, palsy, amenorrhea, } \\
\text { gout and malaria. }\end{array}$ & Not reported & {$[16]$} \\
\hline Blepharis ciliaris & Acanthaceae & Roots, leaves and seeds & $\begin{array}{l}\text { Astrignent, Leukoderma and } \\
\text { wound. }\end{array}$ & Decoction & {$[17]$} \\
\hline Allium sativum & Aliaceae & Not reported & Gastrointestinal disorders. & Not reported & {$[8,18]$} \\
\hline $\begin{array}{l}\text { Abutilon pannosum (G. } \\
\text { Forst.) Schlecht. }\end{array}$ & Malvaceae & Whole plant & Antimicrobial & Not reported & [9] \\
\hline Tamarix aphylla (L.) & Tamaricaceae & Leaves and roots & $\begin{array}{l}\text { Wound infection and } \\
\text { Stomachache. }\end{array}$ & $\begin{array}{l}\text { Decoction of the leaves } \\
\text { and roots }\end{array}$ & [19] \\
\hline $\begin{array}{c}\text { Asphodelus fistulosus } \\
\text { (L.) }\end{array}$ & Liliaceae & $\begin{array}{l}\text { Seeds, bulk and } \\
\text { flowers }\end{array}$ & $\begin{array}{l}\text { Swellings, Anthelmintic } \\
\text { Stomachache }\end{array}$ & Not reported & {$[20]$} \\
\hline Salvadora persica & Salvadoraceae & Roots & $\begin{array}{l}\text { Teeth cleansing, good vision, } \\
\text { deodorant, antihelmintic, blood } \\
\text { tonic, diuretic, and deobstruent. }\end{array}$ & Decoction & {$[14]$} \\
\hline A. obesum (Forssk.) & Apocynaceae & $\begin{array}{c}\text { Milky latex mixed with } \\
\text { cool }\end{array}$ & Skin disease. & Topical & {$[15]$} \\
\hline $\begin{array}{c}\text { Caralluma } \\
\text { quadrangula (Forssk.) }\end{array}$ & Asclepiadaceae & Leaves & $\begin{array}{l}\text { For diabetes, stomachic ulcer and } \\
\text { smallpox. }\end{array}$ & Not reported & {$[16]$} \\
\hline $\begin{array}{c}\text { Adiantum capillus- } \\
\text { veneris }\end{array}$ & Adiantaceae & Whole plant & $\begin{array}{c}\text { Fever, cough, diuretic, } \\
\text { emmenagouge, expectorant, } \\
\text { colds and pulmonary catarrh. }\end{array}$ & $\begin{array}{l}\text { Decoction, juice and } \\
\text { infusion }\end{array}$ & {$[17]$} \\
\hline
\end{tabular}

\section{Conclusion}

The current review discussed 20 species that are reported in Saudi Arabia for traditional uses. This study also reported the medicinal significance of some of these species in the treatment of various diseases. However, more studies should be accomplished for the pharmacological, phytochemical screening and toxicological in order to assure their toxicity profile and biological activity.

\section{Funding}

This research received no external funding.

\section{Institutional Review Board Statement}

Not applicable.

\section{Informed Consent Statement}

Not applicable.

\section{Acknowledgment}

Not applicable. 


\section{References}

1. Al Sodany YM, AB Salih, HAJA Mosallam (2013) Medicinal Plants in Saudi Arabia: I. Sarrwat Mountains at Taif KSA. Journal of Ethnobiology and Ethnomedicine 6(4): 134-145.

2. Alqethami A, AY Aldhebiani, IJ Joe Teixidor Toneu (2020) Medicinal plants used in Jeddah, Saudi Arabia: A gender perspective. Journal of Ethnopharmacology 257: 112899.

3. Alqethami A, AY Aldhebiani (2021) Medicinal plants used in Jeddah, Saudi Arabia: phytochemical screening. Saudi J Biol Sci 28(1): 805-812.

4. Al Sokari, SS El Sheikha, N Sciences (2015) In vitro antimicrobial activity of crude extracts of some medicinal plants from Al-Baha region in Saudi Arabia. Journal of Food and Nutrition Sciences 3(1-2): 74-78.

5. Tounekti T, Mosbah Mahdhi, Habib Khemira (2019) Ethnobotanical study of indigenous medicinal plants of Jazan region, Saudi Arabia. EvidenceBased Complementary and Alternative Medicine, pp. 3190670.

6. Qari SH, Abdulmajeed Fahad Al Refaei, Wessam Filfilan, Alaa Qumsani (2021) Exploration of the Medicinal Flora of the Aljumum Region in Saudi Arabia. Applied Sciences 11(16): 7620.

7. Ullah R, Ali S Alqahtani, Omar M A Noman, Abdulaziz M Alqahtani, Samir Ibenmoussa, et al. (2020) A review on ethno-medicinal plants used in traditional medicine in the Kingdom of Saudi Arabia Saudi J Biol Sci 27(10): 2706-2718.

8. Alyemeni MN, H Sher, L Wijaya (2010) Some observations on Saudi medicinal plants of veterinary importance. Journal of Medicinal Plants Research 4(21): 2298-2304.

9. Aati H, Ali El Gamal, Hamdy Shaheen, Oliver Kayser (2019) Traditional use of ethnomedicinal native plants in the Kingdom of Saudi Arabia. Journal of Ethnobiology and Ethnomedicine 15(1): 1-9.

10. Ghazanfar SA (1994) Handbook of Arabian medicinal plants. In: Ghazanfar SA (Edt.)., CRC press, Boca Raton, Florida, pp. 272.

ISSN: 2574-1241

DOI: $10.26717 /$ BJSTR.2021.39.006359

Bassam SM Al Kazman. Biomed J Sci \& Tech Res

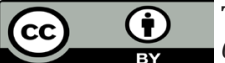

This work is licensed under Creative Commons Attribution 4.0 License

Submission Link: https://biomedres.us/submit-manuscript.php
11. Abdel Zaher AO, Safa Y Salim, Mahmoud H Assaf, Randa H Abdel Hady (2005) Antidiabetic activity and toxicity of Zizyphus spina-christi leaves. J Ethnopharmacol 101(1-3): 129-138.

12. Alzahrani F, Esam Al-Shaebi, Mohamed Dkhil, Saleh Al-Quraishy (2016) In vivo anti-eimeria and in vitro anthelmintic activity of Ziziphus spina-christi leaf extracts. Nanoparticles and natural products against parasites 48(2): 410-413.

13. Chevallier A (2016) Encyclopedia of Herbal Medicine. 550 Herbs and Remedies for Common Ailments. Penguin.

14. Saganuwan AJ (2010) Some medicinal plants of Arabian Pennisula. Journal of Medicinal Plants Research 4(9): 767-789.

15. Ali NAA, Saeed Salah Al Sokari, Ahmed Gushash, Sirajudheen Anwar Khalid Al Karani, et al. (2017) Ethnopharmacological survey of medicinal plants in Albaha Region, Saudi Arabia. Pharmacognosy Res 9(4): 401407.

16. Al Musayeib NM, Ramzi A Mothana, An Matheeussen, Paul Cos, Louis Maes (2012) In vitro anti-plasmodial, antileishmanial and anti-trypanosomal activities of selected medicinal plants used in the traditional Arabian Peninsular region. BMC Complement Altern Med 12(1): 49.

17. Youssef J (2013) Medicinal and non-medicinal uses of some plants found in the middle region of Saudi Arabia. Journal of Medicinal Plants Research 7(34): 2501-2517.

18. Sher H, M Alyemeni (2011) Pharmaceutically important plants used in traditional system of Arab medicine for the treatment of livestock ailments in the kingdom of Saudi Arabia. African Journal Of Biotechnology 10(45): 9153-9159.

19. El Shabasy, Pubs Gupta (2016) Survey on medicinal plants in the flora of Jizan Region, Saudi Arabia. International Journal of Botany Studies 2(1): 38-59.

20. El Ghazali GE, Khalifa S Al Khalifa, Gameel A Saleem, Emad M Abdallah (2010) Traditional medicinal plants indigenous to Al-Rass province, Saudi Arabia. Journal of Medicinal Plants Research 4(24): 2680-2683.

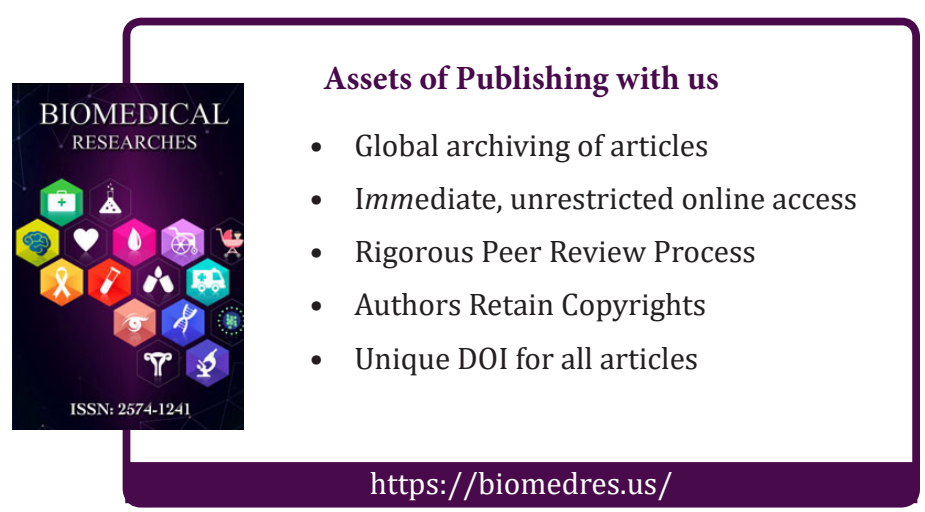

